\title{
A REVIEW ON IN VIVO AND IN VITRO EXPERIMENTAL MODELS TO INVESTIGATE THE ANTI-INFLAMMATORY ACTIVITY OF HERBAL EXTRACTS
}

\author{
INAYAT KABIR, IMTIYAZ ANSARI* \\ Department of Pharmacology, Oriental College of Pharmacy, Sanpada, Navi Mumbai - 400 705, Maharashtra, India. \\ Email: imtiyaz.ansari@ocp.edu.in
}

Received: 24 April 2018, Revised and Accepted: 04 July 2018

\begin{abstract}
The article emphasizes the anti-inflammatory effects of herbal extracts on different experimental models that are repeatedly used to test the in vivo anti-inflammatory activity of herbal components. Edema, granuloma and arthritis models are used to test the anti-inflammatory activity of plant extracts whereas formalin or acetic acid-induced writhing test and hot plate methods are the most repeatedly used to evaluate anti-nociceptive potentials of the herbal extracts. Although adjuvant-induced and collagen-induced arthritis models are also quite efficient, they have been used seldom to evaluate anti-inflammatory tendencies of the herbs. Here, we suggest a double positive reference model using both steroid and nonsteroidal anti-inflammatory drugs at the same time, instead of using only one of them either.
\end{abstract}

Keywords: Anti-inflammatory, Herbal extracts, Experimental models, Carrageenan.

(C) 2018 The Authors. Published by Innovare Academic Sciences Pvt Ltd. This is an open access article under the CC BY license (http://creativecommons. org/licenses/by/4. 0/) DOI: http://dx.doi.org/10.22159/ajpcr.2018.v11i11.26873

\section{INTRODUCTION}

Inflammation is the response of the living system to cell injury. It is a protective mechanism that helps the body to identify and neutralize the noxious stimuli such as bacterial pathogens, toxic chemicals, and cancerous cells by increasing the blood flow to the area of tissue injury. Inflammation is also a great hazard to the patient. It increases the ailment and sufferings of the patient due to pain and morbidity. Arachidonic acid, cyclooxygenase, and lipoxygenase-mediated activation of local inflammatory mediators such as leukotrienes, prostaglandins, prostacyclin, thromboxane $\mathrm{A} 2$, and platelet-activating factor play a key role in tissue destruction and pain associated with inflammation [1,2]. Inflammation often results in puss formation that may hinder the absorption of different antibiotics into the affected tissue that leads to the aggravation of tissue destruction. Hence, it becomes mandatory to administer anti-inflammatory drugs to cure a number of disorders such as infectious diseases in combination with antibiotics. Although a number of different synthetic and semi-synthetic drugs are in use today to combat inflammation, there has always been a thirst to search for the natural anti-inflammatory constituents from various plants and spices. The medicinal importance of spices [63] and herbs is known since ancient times. Most of the today's allopathic medicines are either consisted of herbal extract, or these are the semi-synthetic derivatives of herbal products. Since prehistoric times, herbs are famous in traditional medicine for their anti-inflammatory, antinociceptive, and immunomodulatory activities. Many researchers have directly tested the inhibitory effect of different herbal extracts on the production of inflammatory mediators using different cell culture techniques [3-5]. Such in vitro studies are helpful in developing an understanding of the mechanism of anti-inflammatory activity of herbal compounds; however, most of such in vitro studies are secondary to a preliminary in vivo evaluation of anti-inflammatory properties of plant extracts [6-9]. Different researchers have used different experimental models to evaluate the anti-inflammatory activity of herbal extracts. Here, we have summarized all those in vivo and in vitro methods that are repeatedly being used to evaluate the anti-inflammatory activity of herbs and spices.

\section{IN VIVO SCREENING MODELS}

In these in vivo screening methods, the potency of anti-inflammatory agents is measured by inducing the inflammation in experimental animals such as rats, mice, monkeys, and dogs of either sex can be used.
The inflammation inducers used commonly are carrageenan, mustard, dextran, egg-white, compound 48/80, Yeast, Zymosan-LOX, Serotonin, histamine, Kaolin, Substance -p, nystatin, glass powder, cobra venom, etc. Before starting any in vivo assay, it is important to study the oral acute toxicity study for the selection of test dose. In this, maximum tolerated and minimum toxic dose are calculated by injecting the test dose at an interval of $2 \mathrm{~h}$ in 10, 50,100,200,.., $2000 \mathrm{mg} / \mathrm{kg}$ patterns [10].

\section{Experimental animals}

Some researchers have used big ear albino rabbits [10] most of them have preferred using mice and rats to test the anti-inflammatory activities of herbal extracts. Different types of mice and rats that are frequently used to test the anti-inflammatory effect of herbs include ICR mice [6-8,11-13], Sprague Dawley (SD) rats [6,11,13-16], ddY mice [2], BALB/c [18] and its sub-strain BALB/cj mice [12], C57BL/6 commonly called as black 6 [4], Swiss albino mice $[19,20]$, albino rats [21], and Wistar rats [20,22]. The animals are allowed free access to food (Laboratory chow) and tap water ad libitum. They are accommodated in a specific pathogen-free animal facility (in a laminar air flow room), at a suitable temperature of $22 \pm 1^{\circ} \mathrm{C}$ and $40-60 \%$ RH in a light/dark cycle of $12 \mathrm{~h}[11,12]$ for 2 weeks or more.

\section{Types of screening methods}

Based on the symptoms observed during inflammation in vivo screening methods for anti-inflammatory drugs are characterized into three phases as below [42].

\section{Acute or transient phase}

Vasodilation and increased capillary permeability are perceived.

\section{Sub-acute phase}

In this, infiltration of leukocytes and phagocytes in blood is observed.

Chronic inflammatory phase

Here, granuloma that is tissue degeneration and fibrosis was observed.

\section{IN VIVO SCREENING MODELS}

Carrageenan-induced paw edema in rats $[1,23,27,28,42,61,62]$ A solution of carrageenan in saline is injected subcutaneously in rats induces an acute swelling that becomes maximal after $3-5 \mathrm{~h}$ of the 
injection and subsides by $24 \mathrm{~h}$ [60]. The inflammation produced in this model can be used to measure the production of inflammatory mediators at sites of inflammation, the anti-inflammatory properties of nonsteroidal anti-inflammatory drugs, the efficacy of alleged analgesic compounds to reverse cutaneous sensitivity. This method produces and measures carrageenan-induced inflammation in the footpad, which can be marked as edema and hypersensitivity.

\section{Materials list [60]}

- Male or female rats weighing $>100 \mathrm{~g}$

- $\quad 0.5-2.0 \%(w / v)$ carrageenan solution (Type IV Lambda, Sigma)

- $\quad 0.9 \%(\mathrm{w} / \mathrm{v})$ sterile saline

- Ethanol $(70 \%, v / v)$

\section{Reagents and solutions}

Carrageenan: $0.5-2.0 \%(\mathrm{w} / \mathrm{v})$ carrageenan solution.

Pour $500 \mathrm{ml}$ of sterile $0.9 \%$ saline into a $1 \mathrm{~L}$ beaker and give a stir. Slowly add $2.5 \mathrm{~g}(0.5 \%)-10.0 \mathrm{~g}(2.0 \%)$ carrageenan powder to the beaker. Heat the solution to $90^{\circ} \mathrm{C}$ with continuous stirring; do not allow the solution to boil. Heating the mixture helps to dissolve the carrageenan; it takes $<1 \mathrm{~h}$ to dissolve all of the powder. Pour the solution into a clean and sterile $1 \mathrm{~L}$ glass bottle. After cooling the solution at room temperature equipped into sterile, $100 \mathrm{ml}$ capped bottles. This solution is stable for at least 1 week when stored at $4^{\circ} \mathrm{C}[44]$.

\section{Methodology}

Take male or female SD rats with a body weight between 150 and $170 \mathrm{~g}$. The animals are starved overnight. The animal should be grouped; this grouping is based on test compounds. After 30 minutes, test the rats by subcutaneous injection of $0.05 \mathrm{ml}$ of $1 \%$ solution of carrageenan into the plantar side of the left hind paw. The paw is marked with ink at the level of the lateral malleolus and immersed in the mercury up to the mark [42].

\section{Evaluation}

Measure the paw volume using plethysmometer or micrometer at 3 and $6 \mathrm{~h}$, eventually at $24 \mathrm{~h}$ immediately after the injection. Calculate the increase in paw volume at 3 and $6 \mathrm{~h}$. The percentage increase in paw volume was measured by comparing the difference of the average values between treated group animals and control group animals is calculated at each interval of time. A dose-response curve is run for the active drugs to determine the ED50 values. The treated group animals show much less edema than control group animal [42].

\section{Calculations:}

$\%$ edema produced by carrageenan alone $=\mathrm{A}-\mathrm{B} / \mathrm{B} \times 100=\mathrm{X} \%$

$\%$ edema produced by carrageenan after treating with drug=C-D/ $\mathrm{D} \times 100=\mathrm{Y} \%$

$\%$ reduction of edema by drug $=\mathrm{X}-=---\%[45]$.

\section{Croton oil-induced ear edema}

In this method both rats and mice are used, usually male rats (SD) of 80-60 g are selected, whereas male Swiss mice weighing between 18 and $22 \mathrm{~g}$ are selected. They are grouped according to the body weight. In this approach, a total of $15 \mathrm{mul}$ containing an acetonic solution of $75 \mu \mathrm{g}$ of croton oil is applied to the inner surface of the right ear of each mouse. The animals are previously, anesthetized with diethyl ether at a rate of $0.02 \mathrm{ml}$ in rats and $0.01 \mathrm{ml}$ in mice $[1,34,44]$.

\section{Methodology}

By keeping the left ear untreated, the control group receives the irritant solution; indomethacin is a standard or reference. Changing dose levels of test drug are applied to the inner surface of the right ear of mouse that induces inflammation. When the test and standard drugs are given, the animals are sacrifice by cervical dislocation. Both treated, and untreated ears are removed, and a plug of about $8 \mathrm{~mm}$ diameter is removed from each of the ear. The difference in the weight between two plugs is taken as the measure of edematous response [44].

\section{Evaluation}

This methodology is mainly used to detect the anti-inflammatory activity of steroidal compounds. The percentage anti-inflammatory activity is calculated by Sindhu et al. [44]

$\%$ anti-inflammatory activity $=$ (wt. of the treated ear - wt. of untreated ear/wt. of control ear) *100

\section{Oxazolone-induced ear edema}

This model allows the quantitative estimation of the topical and systemic anti-inflammatory activity of the compound following topical administration

\section{Methodology}

The mice are used as an experimental animal in this model, and they are divided as 12 into each group. Inject $10 \mathrm{ml}$ of $0.5 \%$ of oxazolone in acetone into the right ear and the same was given repetitively 3 times per week, to the sensitized right ear. Acetone alone is given in non-sensitized animals. The mice are again injected with the solution of oxazolone $0.01 \mathrm{ml}$ of $2 \%$ inside the right ear, in which test or standard solutions are resolved. Animals in a group of 10 to 15 are treated with irritant alone or with the test compound solution. The left ear remains untreated and actual inflammation occurs after $24 \mathrm{~h}$. Animals are sacrificed under anesthesia, at this time, and a disc of $8 \mathrm{~mm}$ diameter is punched from both the sides. Allow the disc to dry and weigh on a balance. The difference in weight is an indicator of inflammatory edema [44].

\section{Evaluation}

Calculate average values of the increase in the weight for each treated group and compare statistically with the control group.

\section{UV-B erythema in guinea pigs \\ Methodology}

This method includes that the use of Albino guinea pigs of both the sexes weighing about $350 \mathrm{~g}$ is used. For the treatment and control group, four animals are used. Shave the animals $18 \mathrm{~h}$ before the experiment, on both the sides and on the back, chemically by means of a depilatory cream or with a suspension of barium chloride. The next day dissolves the test compound in the vehicle, and half of it is administered to the animal by gavage, $30 \mathrm{~min}$ before the UV exposure. The control animals are treated only with the vehicle. The guinea pigs are placed in a leather shackle with a hole of $1.5 \mathrm{~cm} \times 2.5 \mathrm{~cm}$ size pierced in it, allowing the UV radiation to reach only this area. Administer the remaining half of the test compound during this time. Normally, the erythema is recorded after 2 and $4 \mathrm{~h}$ of exposure [44].

\section{Evaluation}

Evaluate the degree of erythema by the double-blind method. The following scores are given:

0 - No erythema

1 - Weak erythema

2 - Strong erythema

4 - Very strong erythema

Animals with a score of 0 or 1 are said to be protected. The scoring after 2 and $4 \mathrm{~h}$ indicates some duration of the effect and $\mathrm{ED}_{50}$ values can be calculated [46].

\section{Pleurisy in rats Methodology}

The animal used in the pleurisy test is the mouse. Inject a single dose of $0.1 \mathrm{ml}$ carrageenan intravenously. After $4 \mathrm{~h}$ kill the animal 
with an overdose of ether and wash the pleural cavity with $1.0 \mathrm{ml}$ of sterile phosphate-buffered saline (PBS), containing heparin (20 IU per $\mathrm{ml}$ ). Collect the samples of the pleural lavage and determine the exudation, nitric oxide (NO) levels, adenosine deaminase activities, myeloperoxidase, and total differential leukocyte counts. Perform total leukocyte counts in a Neubauer's Chamber. Analyze the serum level of the C-reactive protein. In another set of experiment treat animals with a solution of Evans blue dye ( $25 \mathrm{mg} / \mathrm{kg}$, i.v.), $30 \mathrm{~min}$ before carrageenan so as to evaluate the degree of exudation in the pleural space [43].

Estimate the amount of dye at $600 \mathrm{~nm}$ by colorimetry using an ELISA Plate Reader, by interpolation from a standard curve of Evans Blue Dye in the range of $0.01-50 \mu \mathrm{g} / \mathrm{ml}$.

\section{Evaluation}

Average and compare the values of each experimental group with that of control. Calculate $\mathrm{ED}_{50}$ values using various doses.

\section{Granuloma air pouch techniques Methodology}

The animals used in this method are male or female SD rats with a body weight between 150 and $200 \mathrm{~g}$. Take 10 animals for control and test groups. Shave and disinfect the back of the animals. Make a pneumoderma, by injecting $20 \mathrm{ml}$ of air under ether anesthesia in the middle of the dorsal skin with a very thin needle, which results in an oval air pouch. Inject $0.5 \mathrm{ml}$ of a $1 \%$ solution of croton oil in sesame oil, avoiding any leakage of air. Remove the air pouch after $48 \mathrm{~h}$ [44].

- Inject the test compound directly into the air sac at the same time as the irritant.

- Sacrifice the animals on the $4^{\text {th }}$ or $5^{\text {th }}$ day under anesthesia.

- Open the pouch and collect the exudate in glass cylinders.

- Evaluate total number of leukocytes migrate into the pouch are after staining with erythrosine B.

\section{Evaluation}

Calculate the average value of the exudates of the control and the test groups. Compare it by statistical means.

\section{Increased vascular permeability by arthus reaction Methodology}

In this method ALBINO Wistar rats are used, 4 rats in each group. Administer distilled water, $1 \% \mathrm{w} / \mathrm{v} 1 \mathrm{ml} / 100 \mathrm{~g}$ by oral route to control group and the test compound to another group by oral route and to the standard group diclofenac $10 \mathrm{ml} / \mathrm{kg}$ by intraperitoneal route. $1 \mathrm{~h}$ after the administration, inject rats with $0.25 \mathrm{ml}$ of $0.6 \% \mathrm{v} / \mathrm{v}$ solution of acetic acid intraperitoneally [50]. Immediately inject $10 \mathrm{ml} / \mathrm{kg}$ of $10 \% \mathrm{w} / \mathrm{v}$ of Evans blue intravenously through the tail vein. Anesthetize the animals after $30 \mathrm{~min}$, with ether anesthesia and sacrifice. Cut the abdomen, open and expose viscera. Hold the animals by a flap of abdominal wall over Petri dish. Collect the peritoneal fluid (exudates), filter and make up the volume up to $10 \mathrm{ml}$ using normal saline solution and centrifuged at $3000 \mathrm{rpm}$ for $15 \mathrm{~min}$. Measure the absorbance (A) of the supernatant at $590 \mathrm{~nm}$ by means of spectrophotometer [56].

\section{Evaluation}

The decrease in the concentration of dye with respect to absorbance indicates the reduction in permeability.

\section{Adjuvant arthritis [29]}

Freund's complete adjuvant-induced arthritis in rat model is the most widely used experimental model for arthritis with clinical and laboratory features that closely mimic the clinical features of human rheumatoid disorder $[1,32,33,49]$. This model is sensitive to antiinflammatory and immunosuppressant medicines and considers being appropriate for the study of pathophysiological and pharmacological control of inflammation progression as well as for the evaluation of the potential of analgesic drugs.

\section{Methodology}

On day zero, inject animals with $0.1 \mathrm{ml}$ of complete Freund's adjuvant (FA) into the subplantar region of the left hind paw. This consist of $6 \mathrm{mg}$ of Mycobacterium butyricum suspended in heavy paraffin oil by grinding with mortar and pestle to give a concentration of $6 \mathrm{mg} / \mathrm{ml}$. Administer dosing with the test and standard compounds on the same day and continue for 12 days as per the following schedule. From day $13^{\text {th }}$ to $21^{\text {st }}$, do not dose the animals with the test or the standard compound. Evaluate by comparing certain parameters between the control and treatment.

\section{Papaya latex-induced arthritis}

Papaya latex-induced arthritis model of experimental rheumatoid arthritis has been developed to test the anti-inflammatory effect of slow reaction antirheumatic drugs. Papaya latex-induced inflammation is supposed to be mediated through prostaglandins $[44,46,47]$.

\section{Methodology}

Prepare $0.25 \%$ solution of papaya latex to take $0.1 \mathrm{ml}$ (prepared in $0.05 \mathrm{M}$ sodium acetate buffer and $\mathrm{pH} 4.5$ with $0.01 \%$ thymol) and inject into the rat back foot (hind paw). The peak effect occurs at $3 \mathrm{~h}$ and continues for more than $5 \mathrm{~h}$. The method is sensitive for evaluating nonsteroidal anti-inflammatory drugs (NSAIDs) such as aspirin, ibuprofen, and nonsteroidal anti-inflammatory drugs $[46,47]$.

\section{Candida albicans induced arthritis \\ Methodology}

Repeated injection with Streptococcus pyogenes cell wall (SCW) fragments into the knee joint of $\mathrm{C} 57 \mathrm{Bl} / 6$ mice produces chronic SCW arthritis alone or in combination with the yeast of $C$. albicans or Zymosan, A. Perform the cytokine levels, mRNA expression and histopathological analysis of the joints during the chronic phase of arthritis. Investigate the phenotype of the interleukin (IL)-17 producing T-cells, isolate and analyze synovial cells by flow cytometry [45].

\section{Arachidonic acid-induced ear edema in mice Materials}

Obtain arachidonic acid, fatty acids, eicosanoids, and histamine (flee base). Dissolve the compounds in a 1:1 (v/v) mixture of tetrahydrofuran and methanol (HPLC grade, Rathbun). CD1 male mice (weighing 20-25 g) and Tuck Wistar male rats (weighing 120-140 g) are used [57,53,54].

\section{Methodology}

Apply $2 \mathrm{mg}$ arachidonic acid in 10 1 tetrahydrofuran:methanol to the inner surface of each ear. Use various amounts of arachidonic acid in ethanol for initial dose-dependency studies. Compounds tested for their inhibitory capacity are normally incorporated in the arachidonic acid solution and applied only to the left ear. Give the only solvent to the control animals on each ear. Kill the animals after $1 \mathrm{~h}$ by cervical dislocation and cutoff both ears at the hairline and weigh. Assess the swelling induced by arachidonic acid as an increase in the weight of the right ears over that of the right ears of solvent-treated control animals, as an amount of the weight of solvent-treated right ears. The swelling induced in the same animals in the presence of test compound was likewise the increase in the weight of the left ears over that of the left ears of the control animals expressed as a proportion of the weight of solvent-treated left ears [52-54].

This value is expressed as percentage of the full (right ear) swelling, and hence a percentage inhibition by the test compound is calculated:

Thus, $\%$ inhibition $=$ [proportional swelling $\sim$ in presence of compound $100-/$ proportional swelling $\times 100$ [in absence of compound $=$ $100-/ \mathrm{L}--7-/-\mathrm{V}-\mathrm{J} \cdot 100$

where

$\mathrm{x}=$ average weight of the left experimental ears

$\mathrm{y}=$ average weight of the left control ears 
$\mathrm{a}=$ average weight of the right experimental ears

$\mathrm{b}=$ average weight of the right control ears

This method reduces the contribution of inter-animal differences in responsiveness to the inflammatory stimuli and also compensates for any consistent bias in cutting off left and right ears. The significance of the inhibition is calculated using a paired t-test of the two values of proportional weight increases. One group of mice is given compound $48 / 80(200 \mu \mathrm{l}$ of a $0.625 \mathrm{mg} / \mathrm{ml}$ solution in sterile saline and equivalent to $5 \mathrm{mg}$ compound/kg body weight) subcutaneously $24 \mathrm{~h}$ before the application of arachidonic acid to the ear [52-54].

\section{Cotton wool edema}

\section{Methodology}

In this method, male rats weighing about 180-200 g are used. Administer the test drugs orally once on a dosage regimen for 7 days and vehicle to the control group. Implant two sterilized pellets of cotton wool subcutaneously, one on each side of the abdomen of the rat, under the ether anesthesia and sterile procedure. Sacrifice the rats on the $8^{\text {th }}$ day, dissect out the implanted pellet and record the wet weight. Dissect out thymuses too. Dry both of these at $60^{\circ} \mathrm{C}$ for $18 \mathrm{~h}$ and record the dry weight $[23,48,49]$

\section{Evaluation}

Calculate the weight of transudate and the granuloma as well as the percent granuloma inhibition of the test drug. Record the body weight gain also.

\section{Glass rod granuloma \\ Methodology}

In this technique, select a glass rod with a diameter of $6 \mathrm{~mm}$ and $40 \mathrm{~mm}$ length. Select male SD rats with an initial weight of $130 \mathrm{~g}$. Anesthetize these rats with ether. Shave and disinfect their back skins. Forma subcutaneous tunnel in the cranial direction with closed blunted forceps by an incision in the caudal region. Introduce the glass rod into this tunnel which lies on the back of the animal. Close the incision wound using sutures. Keep the animals in separate cages; the rods remain in situ for 20 or 40 days. Sacrifice the animals at the end, under $\mathrm{CO}_{2}$ anesthesia. The glass rod is prepared with adjacent connective tissue which forms a tube around the glass rod. Record wet weight of the granuloma tissue, finally dry it and record the dry weight also $[44,50,51]$

\section{Evaluation}

Compare granuloma weight reduced by the test compound with that of the standard.

\section{Sponge implantation technique \\ Methodology}

Prepare the sponges for implantation from polyvinyl foam sheets with a thickness of $5 \mathrm{~mm}$ discs and stamped out to a standard size and weight $(10.0 \pm 0.02 \mathrm{mg})$ using a $13 \mathrm{~mm}$ cork tool. Soak the sponges in $75 \% \mathrm{v} / \mathrm{v}$ ethanol for $30 \mathrm{~min}$, and then heat at $80^{\circ} \mathrm{C}$ for $2 \mathrm{~h}$. Before implantation in the animal, soak the sponges in sterile $0.9 \%$ saline which may contain either drugs antigens or irritants suspended in it. Implant the sponges in female Wistar rats weighing about 150-200 g under ether anesthesia. Make a $20 \mathrm{~mm}$ dorsal incision and separate the dermis from the underlying muscle layer by insertion of blunted forceps to form separate cavities into which the sponges can be inserted. One can implant up to 8 sponges per rat. Close the insertion with Michael clips and maintain the animals at a constant temperature of $24^{\circ} \mathrm{C}$ [51].

\section{Evaluation}

For the estimation of fluid phase of sponge exudates, for example, protein content enzyme levels and biological mediators such as prostaglandins as well as for leukocyte migration, remove sponges after $9 \mathrm{~h}$.
Dextran sulfate sodium-induced colitis in mice

This is a new experimental model of colonic inflammation introduced by Okayasu et al. [1]. In this model an oral administration of sodium salt of a sulfated polysaccharide, dextran sulfate sodium (DSS), is used to induce colitis in the mouse, as well as in other species such as the hamster $[2,3]$ and the rat $[4,5]$. Appearance of the DSS-induced animal colitis is dependent on the molecular weight and sulfation of the DSS, and the dosage and duration of the DSS administration [1,3,6-9]

\section{Animals}

Use specific pathogen-free 6-8-week-old female mice. The mice used are conventional Balb/c and barrier born nu/nu CD-1 (BR) athymic nude mice [25]. Keep the Balb/c mice in standard laboratory conditions with free access to animal chow. By keeping the nu/nu CD-1 animals in disposable cages with filter tops. Radiation-sterilize bedding and autoclave animal chow (R34) for use and keep the animal room and facilities aseptic by spraying them with an aqueous solution of Benzalkonium chloride.

\section{Induction of colitis}

Induce colon inflammation by the administration of DSS in the drinking water. Dissolve DSS with Mw 40-44 kDa and a sulfur content of 15.4$17.0 \%$ in ultra-pure water at concentrations of $2.5 \%$ and $5.0 \%$ with a final $\mathrm{pH}$ of 8.5. Assess the characteristics of the DSS and its stability in solution [7]. Expose the animals to the different DSS solutions ad libitum. Test the water and DSS for bacterial endotoxin contamination.

\section{Inhibition of inflammatory granulation}

This method is used to study the repair phase characterized by fibroblast proliferation and blood vessel formation. Suppression of granulation tissue parallels with anti-inflammatory activity is measured [56].

\section{FA arthritis}

This is the immunologically mediated model of chronic inflammation. It is a delayed hypersensitivity response to mycobacterial Ag. Induction of arthritis is done by subplantar injection of Freund's complete adjuvant or mycobacteria suspended in oil [56].

\section{Day 1 Day 4-5 Day 7}

Local reaction peak systemic disease

Parameters: Foot thickness, wt., grip strength, and deformity are measured.

Evaluation of chronically administered drug against inflammation

Drugs effective: Steroids, immunosuppressants, gold, and d-penicillamine.

\section{Guinea pig model of giant papillary conjunctivitis}

Chronic exposure of contact lenses to foreign bodies leads to GPC. Levels of IL-3, IL-4, IL5, Ig G, Ig E, and Ig M are increased in Tears [56].

\section{Procedure}

Insert a sterile needle directly into conjunctiva of the unsensitised animal. This pricking results in a high number of neutrophil infiltration.

\section{Xylene-induced ear edema in mice}

The acute inflammatory activity of drugs is evaluated using xyleneinduced ear edema in mice as previously described [58,59]. Divide the mice randomly into the following five treatment groups of eight animals each: Vehicle control (distilled water, $20 \mathrm{~mL} / \mathrm{kg}$, p.o.), ASA positive control (100 mg/kg, p.o.), and three doses of drug $(0.8,2.4$, and $7.2 \mathrm{~g} / \mathrm{kg}$, p.o.). Administer these treatments orally for 6 consecutive days. On day 7 at $1 \mathrm{~h}$ after oral administration, apply $30 \mu \mathrm{l}$ of xylene on both the surfaces of the right ear to induce edema. The left ear served as a control. Sacrifice the mice $30 \mathrm{~min}$ after xylene treatment by 
performing cervical dislocation. Remove the right and left ears of the mice with $8 \mathrm{~mm}$ diameter cork borer and weigh the ears. Measure the edema weight difference between the right and left ears of the same animal. Compare the percentage of inhibition with the control group and calculate using the following formula: \%Inhibition=[(Weight of edema (control)-Weight of edema (test)]/Weight of edema (control) $\times 100$ [40].

\section{Monosodium urate crystal-induced arthritis}

The unmetabolized product of purine gets deposited as uric acid in the synovial joint which induces activation of kin in leukotriene B4, accumulation of neutrophil granulocytes characterized by an intermittent attack of Acute Arthritis or Gout. On this, the drugs are injected intradermally at the knee joint to produce arthritis. By Injecting $20 \mathrm{mg}$ sodium urate crystal suspensions in their own knee joint. They experienced severe pain and prostration which resembled an acute gouty attack [49].

\section{Procedure}

Induce inflammation by intradermal injection of $0.2 \mathrm{ml}(4 \mathrm{mg})$ of endotoxin-free monosodium urate crystal suspension into the right foot pad. Day considered as day 0-3. Start treatment with standard and test from day 0 before half hour of MSU and continue for 3 days.

\section{Preparation of monosodium urate crystals}

Dissolve about $4 \mathrm{~g}$ of uric acid in $800 \mathrm{ml}$ water and heat with $\mathrm{NaOH}$ ( $9 \mathrm{ml} / 0.5 \mathrm{~N}$ ), adjust $\mathrm{pH}$ to 8.9 at $60^{\circ} \mathrm{C}$; cool overnight in a cold room; wash and dry. Recover needle-like crystals and suspend in sterile saline $(20 \mathrm{mg} / \mathrm{ml})$

\section{Grip strength of arthritic animals}

In this method, the inducer of arthritis is silver nitrate which is injected in the tibiotarsal joint of rats or by means of intra-articular talc injections in pigeons. This impairs the locomotor activity with inflamed paws. Effective drugs are NSAIDs, steroids, DMARDs, and antihistamines [56].

Inhibition of NO production induced by tumor necrosis factoralpha (TNF- $\alpha$ ) in mouse macrophages

Animals

Mice C57BL/6.

\section{Infection and treatment with $m A b$ against TNF- $\alpha$}

Subcutaneously infect resistant C57BL/6 mice in the footpad with $2 \times 10^{6}$ promastigote forms in stationary phase. Inject the animals i.p. with $500 \mu \mathrm{g}$ anti-TNF- $\alpha$ mAb (XT22.11), $2 \mathrm{~h}$ before the infection, followed by twice a week until the $12^{\text {th }}$ week after infection. Control mice are untreated or treated with $500 \mu \mathrm{g}$ rat purified immunoglobulin $\mathrm{G}(\mathrm{nIgG})$. For 3 days before the infection, treat the animals with nIgG or anti-TNF- $\alpha$ were daily treated orally with $5 \mathrm{mg}$ rat $\operatorname{IgG}$, to make them tolerant to IgG $[21,41]$.

\section{Determination of disease progression}

Monitor the development of lesions by measuring the increase in footpad thickness as compared to the uninfected one. Determine the number of parasites in the lesion by a modified limiting dilution analysis applying Poisson statistics and the $\chi^{2}$-minimization method, using a computer program (ELIDA) [55].

\section{Determination of serum nitrate concentration}

The nitrate $\left(\mathrm{NO}_{3}^{-}\right)$presents in the serum samples are obtained from infected and TNF- $\alpha$ mAb-treated animals and are reduced to nitrite with nitrate reductase and determine the nitrate concentration by the Griess method $[26,56]$.

\section{Inducible nitric oxide synthase (iNOS) activity assay [39]}

Collect the popliteal lymph nodes from C57BL/6 mice treated with anti-TNF- $\alpha$, nIgG, or saline at the $2^{\text {nd }}, 6^{\text {th }}$, and $12^{\text {th }}$ weeks after infection with L. major, and determine iNOS activity by measuring the formation of ${ }^{14} \mathrm{C}$ citrulline as described [57]. iNOS activity is expressed as pmol citrulline/mg protein/h.

\section{Immunolocalization of iNOS in macrophages and neutrophils on} footpad lesions

Insert the footpad tissues and draining lymph nodes in OCT compound, freeze and store at $-70^{\circ} \mathrm{C}$. Place the tissue sections of $5 \mu \mathrm{m}$ thick, on L-poly-lysine-coated slides fixed in acetone, and block nonspecific protein binding with goat serum (diluted 1:200 in PBS) for 45 min. Incubate the slides with primary rabbitanti-mouse iNOS antibody (Santa Cruz Biotechnology, CA; diluted 1:200 in PBS plus 1\% BSA) overnight. The reaction product is detected with avidin-biotin-peroxidase complex (Vector Laboratories, Burlingame, CA), and develop the color of the reaction with diaminobenzidine tetrahydrochloride (DAB; Sigma, St. Louis, MO). Counterstain the slides with Mayer's hematoxylin. Score the observed intensity of the reaction on the slides as absent, discrete, moderate, or intense $[55,56]$.

\section{IN VITRO SCREENING MODELS}

\section{coX assay}

COX-1

Add $10 \mathrm{ml}$ of the sample solution to $19 \mathrm{ml}$ of $0.1 \mathrm{M}$ of L-adrenaline, dihydrogen tartrate, and $10 \mathrm{mM}$ of hematin. After adding $0-2$ units of COX-1 pre-incubate for $5 \mathrm{~min}$ by adding $10 \mathrm{~mL}$ of $10 \%$ formic acid. Measure the PGE2 concentration with a PGE2 enzyme immune assay [41].

\section{COX-2}

Prepare assay mixture with $100 \mathrm{~mm}$ rod phosphate, $1 \mathrm{~mm}$ of hematin gelation, $2.5 \mathrm{~mL}$ of the compound in DMSO. It is to be pre-incubated for $15 \mathrm{~min}$ at $22^{\circ} \mathrm{C}$ and add the $20 \mathrm{ml}$ of $1 \mathrm{mM}$ arachidonic acid solution and 1 $\mathrm{mM}$ Thermal power management device (TPMD) in assay buffer. Measure the absorbance at $400 \mathrm{~nm}$ over the fast $36 \mathrm{~s}$ and calculate percentage inhibition. Observe the enzyme inhibition of TPMD in the absence of COX2 and subtract from activity in the presence of COX-2 $[35,41]$.

\section{Mast cell degranulation}

Inject heparinized Tyrode solution into the peritoneal cavity of exsanguinated rat (SD) after the abdominal massage, harvest and separate the cells in peritoneal fluid through 38\% Bovine Serum Albumin. Wash the cells and suspend in Tyrode solution with $0.1 \%$ BSA. Pre-incubate the cell suspension with test drugs at $37^{\circ} \mathrm{C}$ for 3 min,15 mins after addition of compound 48/80 (standard compound for mast cell degranulation), glucuronidase (1mM Phenolphthalein-Dglucuronide in $0.1 \mathrm{M}$ acetic acid buffer, $\mathrm{pH} 4.5$ is used as a substrate, and monitor absorbance at $550 \mathrm{~nm}$ after alkalization), and histamine $(0.2 \%$ o-phthalaldehyde condensation in $\mathrm{pH} 12.5$ fluorescence is monitored at $350 / 450 \mathrm{~nm}$ after acidification) in the supernatant is determined. Measure the total content after treatment of the cell suspension with Triton X-100. Determine the percentage release as the index of antiinflammatory activity [41].

\section{Platelet-neutrophils adhesion}

Thrombin-activated human platelets are incubated with the drug at $20^{\circ} \mathrm{C}$ for $10 \mathrm{~min}$ and mixed with neutrophils at a ratio of $10: 1$. Neutrophil with two or more (number positives) and one or no adherent platelets (number negatives) is counted as an index of activity. The test drug blocks the adhesion with respect to controls [41].

\section{Cell viability}

Cell viability is evaluated using a 3-(4,5-dimethyl-thiazole-2-yl)2,5-diphenyl tetrazolium bromide (MTT)-based colorimetric assay (Diaz-Lanza et al., 2001). Pipette cells $\left(8 \times 10^{5}\right)$ diluted with Dulbecco's modified Eagle's medium with $10 \%$ heat-inactivated fetal calf serum (FCS) into 96-well microtiter plates and were incubated overnight at $37^{\circ} \mathrm{C}$ and $5 \% \mathrm{CO}_{2}$. They were exposed to various concentrations of samples for $3 \mathrm{~h}$ under the same conditions of incubation. MTT solution dissolved in phosphate-buffered saline was added to the wells at 
$1 \mathrm{mg} / \mathrm{ml}$ final concentration. After carefully aspirating the medium, $100 \mu \mathrm{L}$ of DMSO was added for the dissolution of formazan crystals. The absorbances of all wells were then read at $520 \mathrm{~nm}$ using a microplate reader. The values of the maximum non-toxic concentration obtained were used in $\mathrm{PGE}_{2}$ and $\mathrm{LTB}_{4}$ determination [41].

Apart from these methods following methods are used for the screening of anti-inflammatory drugs:

Formalin induced paw oedema $[24,36]$

Streptococcal cell wall (SCW) arthritis [30]

Collagen-induced arthritis (CIA) mouse model [31]

Cell-based reporter gene assay

FMLP-induced $\mathrm{O}_{2}$ generation by poly morpho nuclear cells (PMNs).

FMLP-induced adhesion of PMN of HUVEC

3-H bradykinin receptor binding [49]

3-H Substance P receptor binding

Assay of PMNL chemotaxis

PMNL aggregation constitutive and inducible cellular arachidonic acid metabolism

Formation of leukotriene B4 in human white blood cells

Formation of lipoxygenase products from 14C-arachidonic acid in human PMN

Formation of eicosanoids from $14 \mathrm{C}$-arachidonic acid in human platelets Bovine serum-induced inflammation [37]

HRBC membrane stabilization method.

\section{ACKNOWLEDGMENT}

We are grateful to our Principal Dr. (Mrs.) Sudha Rathod, Dr. (Mrs.) Vanita G. Kanase, and Dr. Sayyed Mateeen for their guidance and support as well as to Pharmacology Department, Oriental College of Pharmacy, Navi Mumbai.

\section{AUTHOR'S CONTRIBUTIONS}

We declare that this work was done by the authors named in this article and all liabilities pertaining to claims relating to the content of this article will be borne by the authors. Ms. Inayat I. Kabir collected the data and analyzed the data. Mr. Imtiyaz Ansari proof-read the whole manuscript, and suggested the necessary changes, and helps in designing manuscript.

\section{CONFLICTS OF INTEREST}

The authors declare that there are no conflicts of interest regarding the publication of this paper.

\section{REFERENCES}

1. Umar MI, Altaf R, Iqbal MA, Sadiq MB. In vivo experimental models to investigate the anti-inflammatory activity of herbal extracts (review). Sci Int 2010;22:199-203.

2. Graham JE, Robles TF, Kiecolt-Glaser JK, Malarkey WB, Bissell MG, Glaser $\mathrm{R}$, et al. Hostility and pain are related to inflammation in older adults. Brain Behav Immun 2006;20:389-400.

3. Wiart C. Anti-inflammatory plants, ethnopharmacology of medicinal plants. Asia Pac 2006;55:1-55.

4. Choi IY, Kim SJ, Jeong HJ, Park SH, Song YS, Lee JH, et al. Hesperidin inhibits expression of hypoxia inducible factor- 1 alpha and inflammatory cytokine production from mast cells. Mol Cell Biochem 2007;305:153-61.

5. Sur R, Martin K, Liebel F, Lyte P, Shapiro S, Southall M, et al. Antiinflammatory activity of parthenolide-depleted feverfew (Tanacetum parthenium). Inflammopharmacology 2009;17:42-9.

6. An HJ, Jeong HJ, Lee EH, Kim YK, Hwang WJ, Yoo SJ, et al. Xanthii fructus inhibits inflammatory responses in LPS-stimulated mouse peritoneal macrophages. Inflammation 2004;28:263-70.

7. Kim DW, Son KH, Chang HW, Bae K, Kang SS, Kim HP, et al. Anti-inflammatory activity of elsholtzia splendens. Arch Pharm Res 2003;26:232-6.

8. Liu X, Hu Z, Shi Q, Zeng H, Shen Y, Jin H, et al. Anti-inflammatory and anti-nociceptive activities of compounds from Tinospora sagittata (Oliv.) gagnep. Arch Pharm Res 2010;33:981-7.
9. Jang SI, Kim BH, Lee WY, An SJ, Choi HG, Jeon BH, et al. Stylopine from Chelidonium majus inhibits LPS-induced inflammatory mediators in RAW 264.7 cells. Arch Pharm Res 2004;27:923-9.

10. Lim H, Jung HA, Choi JS, Kim YS, Kang SS, Kim HP, et al. Antiinflammatory activity of the constituents of the roots of aralia continentalis. Arch Pharm Res 2009;32:1237-43.

11. Yu-sheng L, Ming-Zhen L, Wang-Yun YE. Inhibitory action of Chinese medicinal preparation anti-inflammatory agent No. 6 on DIC resulting from endotoxin, experimental study. Acta Acad Med Wuhan 1985;5:23-9.

12. Tapondjou LA, Lontsi D, Sondengam BL, Choi J, Lee KT, Jung HJ, et al. In vivo anti-nociceptive and anti-inflammatory effect of the two triterpenes, ursolic acid and 23-hydroxyursolic acid, from Cussonia bancoensis. Arch Pharm Res 2003;26:143-6.

13. Choi YH, Son KH, Chang HW, Bae K, Kang SS, Kim HP, et al. New anti-inflammatory formulation containing synurus deltoides extract. Arch Pharm Res 2005;28:848-53.

14. Kang TH, Choi IY, Kim SJ, Moon PD, Seo JU, Kim JJ, et al. Ailanthus altissima swingle has anti-anaphylactic effect and inhibits inflammatory cytokine expression via suppression of nuclear factorkappaB activation. In Vitro Cell Dev Biol Anim 2010;46:72-81.

15. Yam MF, Ang LF, Basir R, Salman IM, Ameer OZ, Asmawi MZ. Evaluation of the antipyretic potential of Orthosiphon stamineus Benth standardized extract. Inflammopharmacology 2009;17:50-4.

16. Chen X, Feng XW. Effects of anti-inflammatory agent no. 6 for injection on the oxidative burst of rat peritoneal macrophages. J Tongji Med Univ 1987;7:65-9.

17. Bukhari IA, Khan RA, Gilani AU, Shah AJ, Hussain J, Ahmad VU, et al. The analgesic, anti-inflammatory and calcium antagonist potential of Tanacetum artemisioides. Arch Pharm Res 2007;30:303-12.

18. Kim KH, Kim S, Jung MY, Ham IH, Whang WK. Anti-inflammatory phenylpropanoid glycosides from Clerodendron trichotomum leaves. Arch Pharm Res 2009;32:7-13.

19. Ha ES, Hwang SH, Shin KS, Yu KW, Lee KH, Choi JS, et al. Antimetastatic activity of glycoprotein fractionated from Acanthopanax senticosus, involvement of NK-cell and macrophage activation. Arch Pharm Res 2004;27:217-24.

20. Bawankule DU, Chattopadhyay SK, Pal A, Saxena K, Yadav S, Faridi U, et al. Modulation of inflammatory mediators by coumarinolignoids from Cleome viscosa in female Swiss albino mice. Inflammopharmacology 2008;16:272-7.

21. Dugasania S, Rao M, Vishna P, Nadarajahe D, Katyayani M, Satyanarayana B, Jayaveera T, Korlakuntab N. Comparative antioxidant and anti-inflammatory effects of [6]-gingerol, [8]-gingerol, [10]-gingerol and [6]-shogaol. J Ethnopharmacol 2010;127:515-20.

22. Aly AM, Al-Alousi L, Salem HA. Licorice: A possible anti-inflammatory and anti-ulcer drug. AAPS PharmSciTech 2005;6:E74-82.

23. Owoyele BV, Adebukola OM, Funmilayo AA, Soladoye AO. Antiinflammatory activities of ethanolic extract of Carica papaya leaves. Inflammopharmacology 2008;16:168-73.

24. Damas J, Liégeois JE. The inflammatory reaction induced by formalin in the rat paw naunyn schmiedeberg's. Arch Pharmacol 1999;359:220-7.

25. Pedernera AM, Guardia T, Calderón CE, Rotelli AE, de la Rocha NE, Saad JR, et al. Anti-inflammatory effect of Acacia visco extracts in animal models. Inflammopharmacology 2010;18:253-60.

26. Tripathi YB, Reddy MM, Pandey RS, Subhashini J, Tiwari OP, Singh BK, et al. Anti-inflammatory properties of BHUx, a polyherbal formulation to prevent atherosclerosis. Inflammopharmacology 2004;12:131-52.

27. Manni L, Aloe L. Role of IL-1b and TNF-an in the regulation of NGF in experimentally induced arthritis in mice. Rheumatol Int 1998;18:97-102.

28. Aloe L, Tuveri MA, Levi-Montalcini R. Studies on carrageenaninduced arthritis in adult rats: Presence of nerve growth factor and role of sympathetic innervation. Rheumatol Int 1992;12:213-6.

29. Yang Y, Leech M, Hutchinson P, Holdsworth SR, Morand EF. Antiinflammatory effect of lipocortin 1 in experimental arthritis. Inflammation 1997;21:583-96.

30. Janusz MJ, Durham SL. Inhibition of cartilage degradation in rat collagen-induced arthritis but not adjuvant arthritis by the neutrophil elastase inhibitor MDL 101,146. Inflamm Res 1997;46:503-8.

31. Yoshida H, Hashizume M, Mihara M. IL-6 blockade preferentially inhibits th17 differentiation in collagen-induced arthritis. Rheumatol Int 2011;31:127-31.

32. Meunier CJ, Verbeeck RK. Glucuronidation kinetics of R,S-ketoprofen in adjuvant-induced arthritic rats. Pharm Res 1999;16:1081-6.

33. Reddy GK, Dhar SC. Studies on carbohydrate moieties of glycoproteins in established adjuvant induced arthritis. Agents Actions 1988;25:63-70.

34. Reanmongkol W, Noppapan T, Subhadhirasakul S. Antinociceptive, 
antipyretic, and anti-inflammatory activities of Putranjiva roxburghii wall. Leaf extract in experimental animals. J Nat Med 2009;63:290-6.

35. Sulaiman MR, Zakaria ZA, Daud IA, Ng FN, Ng YC, Hidayat MT, et al. Antinociceptive and anti-inflammatory activities of the aqueous extract of Kaempferia galanga leaves in animal models. J Nat Med 2008;62:221-7.

36. Nalepa I, Vetulani J, Borghi V, Kowalska M, Przewlocka B, Pavone F. Formalin hindpaw injection induces changes in the $[3 \mathrm{H}]$ prazosin binding to a1-adrenoceptors in specific regions of the mouse brain and spinal cord. J Neural Transm 2005;112:1309-19.

37. Kapewangolo P, Omolo JJ, Bruwer R, Fonteh P, Meyer D, Kapewangolo P, et al. Licensee BioMed Central. Antioxidant and antiinflammatory activity of Ocimum labiatum extract and isolated labdane diterpenoid. J Inflamm 2015;12:4.

38. Lantz RC, Chen GJ, Solyom AM, Jolad SD, Timmermann BN. The effect of turmeric extracts on inflammatory mediator production. Phytomedicine 2005;12:445-52.

39. Lantz RC, Chen GJ, Sarihan M, Sólyom AM, Jolad SD, Timmermann BN, et al. The effect of extracts from ginger rhizome on inflammatory mediator production. Phytomedicine 2007;14:123-8.

40. Zhu Y, Shi H, Cheng X, Wang C, Cheng J. In in vivo evaluation of the anti-inflammatory and analgesic activities of compound Muniziqi granule in experimental animal models. BMC Complement Altern Med 2016;16:20

41. Fonseca SG, Romão PR, Figueiredo F, Morais RH, Lima HC, Ferreira SH, et al. TNF-alpha mediates the induction of nitric oxide synthase in macrophages but not in neutrophils in experimental cutaneous leishmaniasis. Eur J Immunol 2003;33:2297-306.

42. Battu GR, Parimi R, Chandra Shekar KB. In vivo and in vitro pharmacological activity of Aristolochia tagala (syn: Aristolochia acuminata) root extracts. Pharm Biol 2011:49:1210-4.

43. Hulkower KI, Pollock JS, Walsh RE, Huang R, Otis ER, Brooks CD, et al. Leukotrienes do not regulate nitric oxide production in RAW 264.7 macrophages. Prostaglandins Leukot Essent Fatty Acids 1996;55:145-9.

44. Sindhu RK, Sood N, Puri V, Arora S. Various animal models for preclinical testing of anti-inflammatory agents. Int J Pharm Sci Res 2017;8:1550-7.

45. Marijnissen RJ, Koenders MI, van de Veerdonk FL, Dulos J, Netea MG, Boots AM, et al. Exposure to Candida albicans polarizes a T-cell driven arthritis model towards th17 responses, resulting in a more destructive arthritis. PLoS One 2012;7:e38889.

46. Sindhu RK, Arora S. Therapeutic effect of Ficus lacor aerial roots of various fractions on adjuvant-induced arthritic rats. ISRN Pharmacol 2013;2013:634106.

47. Warren JB, Loi RK, Coughlan ML. Involvement of nitric oxide synthase in the delayed vasodilator response to ultraviolet light irradiation of rat skin in vivo. Br J Pharmacol 1993;109:802-6.

48. Bouriche H, Kada S, Assaf AM, Senator A, Gül F, Dimertas I. Phytochemical screening and anti-inflammatory properties of Algerian Hertia cheirifolia methanol extract. Pharm Biol 2016;9:1-7.
49. Martin SW, Stevens AJ, Brennan BS, Davies D, Rowland M, Houston JB, et al. The six-day-old rat air pouch model of inflammation: Characterization of the inflammatory response to carrageenan. J Pharmacol Toxicol Methods 1994;32:139-47.

50. Pires AF, Rodrigues NV, Soares PM, Ribeiro Rde A, Aragão KS, Marinho MM, et al. A novel N-acetyl-glucosamine lectin of Lonchocarpus araripensis attenuates acute cellular inflammation in mice. Inflamm Res 2016;65:43-52.

51. Smita S, Shwetha K, Prabhu K, Maradi R, Bairy KL, Shanbhag T. Evaluation of anti-inflammatory activity of Tephrosia purpurea in rats. Asian Pac J Trop Med 2010;3:193-5.

52. Garrido G, González D, Lemus Y, García D, Lodeiro L, Quintero G, et al. In vivo and in vitro anti-inflammatory activity of Mangifera indica L. Extract (VIMANG). Pharmacol Res 2004;50:143-9.

53. Garcia-Pastor P, Randazzo A, Gomez-Paloma L, Alcaraz MJ, Paya M. Effects of petrosaspongiolide $\mathrm{M}$, a novel phospholipase A2 inhibitor, on acute and chronic inflammation. J Pharmacol Exp Ther 1999;289:166-72.

54. Romay C, Ledón N, González R. Further studies on anti-inflammatory activity of phycocyanin in some animal models of inflammation. Inflamm Res 1998:47:334-8.

55. Taswell C. Limiting dilution assays for the separation, characterization and quantitation of biologically active particles and their clonal progeny. In: Pretlow TG, Pretlow TP, editors. Cell Separation: Methods and Selected Applications. New York: Academic Press; 1986. p. 109-45.

56. Green LC, Tannenbaum SR, Goldman P. Nitrate synthesis in the germ free and conventional rat. Science 1981;212:56-8

57. Salter M, Knowles RG, Moncada S. Widespread tissue distribution, species distribution and changes in activity of $\mathrm{ca}(2+)$-dependent and ca(2+)-independent nitric oxide synthases. FEBS Lett 1991;291:145-9.

58. Hosseinzadeh H, Ramezani M, Salmani G. Antinociceptive, antiinflammatory and acute toxicity effects of Zataria multiflora boiss extracts in mice and rats. J Ethnopharmacol 2000;73:379-85.

59. Olajide OA, Awe SO, Makinde JM, Ekhelar AI, Olusola A, Morebise $\mathrm{O}$, et al. Studies on the anti-inflammatory, antipyretic and analgesic properties of Alstonia boonei stem bark. J Ethnopharmacol 2000;71:179-86

60. Fehrenbacher JC, Vasko MR, Duarte DB. Models of inflammation: Carrageenan- or complete Freund's adjuvant (CFA)-induced Edema and hypersensitivity in the rat. Curr Protoc Pharmacol 2012; Chapter 5:Unit5.4

61. Hossain H, Shahid-Ud-Daula AF, Jahan IA, Nimmi I, Maruf KM, Hassan M. Evaluation of anti-inflammatory activity and determination of total flavonoids and tannin contents of Lagenaria siceraria root. Int J Pharm Sci Res 2012;3:2679.

62. Mondal S, Bandopadhyay A. The wonders of a medicinal tree: Holoptelea integrifolia (Roxb.) planch. Int J Pharm Pharm Sci 2016;8:43-8.

63. Balijepalli1 MK, Buru AS, Sakirolla R, Pichika MR. Cinnamomum Genus: A review on its biological activities. Int J Pharm Pharm Sci 2017;9:1-11 